University of Wollongong

Research Online

Faculty of Business - Papers (Archive)

Faculty of Business and Law

$1-1-2017$

A review of research on regulation changes in the Asia-Pacific region

Millicent M. Chang

University of Western Australia, mchang@uow.edu.au

Andrew B. Jackson

University of New South Wales

Marvin Wee

University of Western Australia

Follow this and additional works at: https://ro.uow.edu.au/buspapers

Part of the Business Commons

Research Online is the open access institutional repository for the University of Wollongong. For further information contact the UOW Library: research-pubs@uow.edu.au 


\title{
A review of research on regulation changes in the Asia-Pacific region
}

\author{
Abstract \\ In this study, we review the financial research on regulation in the Asia-Pacific region. We do this by \\ analysing six leading regional accounting and finance journals - Abacus, Accounting \& Finance, Australian \\ Accounting Review, Australian Journal of Management, International Review of Finance and the Pacific- \\ Basin Finance Journal. We identify five main themes of regulation research relating to: (i) banking and \\ financial institutions, (ii) markets and trading, (iii) corporate governance, (iv) disclosure and (v) accounting \\ standard setting. Our paper synthesises the regional literature in these areas and provide some \\ suggestions for future directions. \\ Disciplines \\ Business \\ Publication Details \\ Chang, M., Jackson, A. B. \& Wee, M. (2017). A review of research on regulation changes in the Asia-Pacific \\ region. Accounting and Finance, 58 (3), 635-667.
}




\title{
A Review of Research on Regulation Changes in the Asia-Pacific $\operatorname{Region}^{\dagger}$
}

\author{
Millicent Chang \\ UWA Business School, The University of Western Australia \\ Andrew B. Jackson \\ UNSW Business School, UNSW Australia \\ Marvin Wee \\ UWA Business School, The University of Western Australia
}

We acknowledge the comments of an anonymous reviewer, Jeff Coulton and Tom Smith. Corresponding author: Andrew Jackson, a.b.jackson@unsw.edu.au. 


\title{
A Review of Research on Regulation Changes in the Asia-Pacific Region
}

\begin{abstract}
:
In this paper, we review the financial research on regulation in the Asia-Pacific region. We do this by analysing six leading regional accounting and finance journals - Abacus, Accounting \& Finance, Australian Accounting Review, Australian Journal of Management, International Review of Finance and the Pacific-Basin Finance Journal. We identify five main themes of regulation research relating to: (1) banking and financial institutions; (2) markets and trading; (3) corporate governance; (4) disclosure; and (5) accounting standard setting. Our paper synthesises the regional literature in these areas and provide some suggestions for future directions.
\end{abstract}

\section{JEL classification:}

Keywords: Regulation, Finance, Accounting, Financial Institutions, Trading, Corporate Governance, Disclosure, Standard Setting 


\section{Introduction}

In this review we synthesise the empirical research broadly dealing with financial regulation in the Asia-Pacific region, in the spirit of Benson et al. (2014), Benson et al. (2015a), and Benson et al. (2015b). Research on regulation contributes in an important capacity to the general economic environment as rules and legislation have the power to alter the behaviour of providers and users of information in the capital markets. Business scholars are often criticised for not being relevant to practice. However, as Taylor (2009) points out, when it comes to research around regulation, there are inherent difficulties in conducting timely research. This is mainly due to empirical research being governed by available data, meaning that studies cannot be conducted of phenomena that cannot be observed.

Regulation research can cover a broad array of topics within the accounting and finance disciplines. In our review, we take regulation to cover a spectrum of regulated activity with a network of actors. Regulation research then acts as an umbrella term to describe a range of research questions driven by changes in the world of business, finance and accounting. Rather than taking any overarching theme or theory in our review, we allowed the published research to drive our themes based on the main types of regulation we identify. As such, the themes we identified cover a broad range of types of regulation, including international policy, domestic legislation, reporting frameworks, and best practice guidelines. It is also worth noting that many of the research papers we identified did not necessarily relate to any specific regulation, but rather, they include concluding remarks that the results of the studies may be of interest to regulators to make appeals to the marginal contribution of their findings.

In identifying the themes, we began by selecting regional accounting and finance journals that most prominently feature regulation research. The initial identification criterion was A ranked journals from the Asia Pacific region on the Australian Business Deans' Council (ABDC) list. $^{1}$ We extended the selection to include Australian Accounting Review, a B ranked journal, because it is predominantly a practitioner journal with a heavy regulatory focus. This process resulted in six journals being selected: Abacus, Accounting \& Finance, Australian Accounting Review, Australian Journal of Management, International Review of Finance and Pacific Basin Finance Journal. ${ }^{2}$ Table 1 reproduces the discussion of the aims

\footnotetext{
${ }^{1}$ There are no $A^{*}$ ranked journals in accounting and finance from the Asia Pacific region.

${ }^{2}$ We acknowledge from this list we have excluded Accounting Auditing and Accountability Journal (AAAJ). The reason for this omission is that we are focussed on empirical archival regulatory research. AAAJ has published a number of articles on regulation, however, this is more of a critical perspectives approach and deals more with the regulation of the accounting profession as opposed to specific financial regulations. It is not our
} 
and scope of each journal. From these journals, we performed full text searches using each journal's search function for 'regulation'. To keep the review manageable, we selected 1990 as the start year and ended our analysis in 2015, which represents the last quarter century of regulation research in the Asia Pacific region. Because of this process, we ascertained five main themes of regulation research relating to: (1) banking and financial institutions; (2) markets and trading; (3) corporate governance; (4) disclosure; and (5) accounting standard setting.

[Insert Table 1 about here]

Table 2 provides summary statistics on the papers reviewed and included in our discussion of the five themes of regulation research. While these five main themes have been identified, it is not an exhaustive list of themes in regulation research. Additionally, within the themes, we acknowledge that not every paper has been selected. Likewise, our effort does not attempt to provide a history of how various regulations and regulatory bodies have emerged through history. Prior studies have covered this in more rigour than is within the scope of this review. For example, Brown and Tarca (2007) review the history of the Australian Investment and Securities Commission (ASIC), Previts et al. (2003) recount the background to activities of the Securities Exchange Commission (SEC) in the U.S., and Miller (1995) provides an overview of the emergence of standard setting regulation in Australia. Furthermore, we also do not attempt to provide theories for why regulation occurs.

[Insert Table 2 about here]

One trend we observe is a lack of 'research debate' surrounding regulatory issues. For the majority of papers we review, little is done to explicitly confirm prior research, or provide conflicting viewpoints. Each paper tends to approach each research question in isolation from the prior literature, and cites prior research in a limited nature even when it is directly related to the issue at hand. While we do not provide a formal analysis, ${ }^{3}$ this trend is consistent with Linnenluecke et al. $(2016,73)$ conclusion that the lack of cross citation of papers is "a sign of immaturity in the research community." Indeed in relatively more mature disciplines such as

intention to slight this line of research, and indeed we acknowledge the importance of a broad range of worldviews to further our understanding of regulatory practices.

${ }^{3}$ Hubbard and Vetter (1996) find replication or extension type studies constitute less than $10 \%$ of published empirical work in accounting and finance research. 
science, replications and meta-analysis is acceptable within the research communities and often encouraged (Moonesinghe et al. 2007). With this review, we hope to help future authors address this perceived immaturity to grow the regulatory research conversation in the region.

\section{Banking and Financial Institutions Regulation}

Many papers have addressed regulation in the banking and financial institutions sector. Typical justifications for regulatory intervention include market failure which impacts on economic efficiency, safeguarding the system against risk, and protection of customers against opportunistic behaviour by those who supply financial services (Carmichael 2001). A change in regulation meanwhile is normally justified because the cost of market failure is greater than the cost associated with intervention or regulatory change.

Papers examining the impact of new regulation include Chong et al. (1996) on the effect of the Financial System Reform Act (FSRA) of 1992 on the Japanese financial services industry; Davis (1994) on prudential regulation of non-bank financial institutions in Australia, specifically the effect on cooperative financial institutions, such as credit unions; and Yan et al. (2014) on the consequence of the 2008 deposit and wholesale funding guarantee on depositor market discipline of Australian banks. Bátiz-Lazo and Billings (2012) document some unintended consequences of regulatory change in a case study of a major British mutual financial organization where accounting manipulation occurred to offset the unfavourable impact of new regulation. Francis and Osborne (2010) evaluate the role of regulatory capital requirements for banks in the UK and report that even though some of these requirements were non-binding, they affected their capital management practices.

The Wallis Inquiry reported on the consequences of financial deregulation of the Australian financial system that had been occurring since the early 1980s. Hogan (1997), a critique of the Wallis Inquiry, suggests that due to time constraints, the panel was unable to consider fully the consequences of proposed changes to the system of financial supervision and regulation in Australia. More recently, Avkiran et al. (2015) examine the effects of the relaxation of regulatory requirements imposed on foreign banks in China on their ability to compete. In another Chinese study, Fu et al. (2015) examine the impact of ownership and governance structures on Chinese banks' reaction to regulatory pressure. They find that the degree of central government ownership and the CEO's political ties play important roles in the risk-taking behaviour of banks.

The reactions of banks and other financial institutions to market failures have been the subject of a few papers. For example, Agusman et al. (2014) examine the Indonesian 
government's reaction to the 1997/1998 financial crisis where the government was forced into capital injection (to selected banks), and introduced deposit insurance and changes to capital requirements. Allen and Carletti (2010) ponder the antecedents of the Global Financial Crisis, suggesting that the real estate bubble in the US and other countries was the result of loose monetary policy, global imbalances, cheap credit, and the easy availability of funds. They consider possible reforms to reduce occurrences of future crises including changes to the governance structure of central banks, modifications to banking regulation, and steps to reduce global imbalances. Angkinand et al. (2010) turn their attention to banking crises, suggesting they are most likely after an intermediate degree of liberalisation. Using financial reform data from 48 countries between 1973 and 2005, they report the relationship between liberalisation and likelihood of crisis to be an inverted U. The effectiveness of government involvement and banking regulations worldwide in delivering a risk reward trade-off that is balanced to shareholders of banks in both crisis and normal times is investigated in Hossain et al. (2013). Kane (2000) argues that banking crises become more severe with disinformation on losses incurred by banks in making politically directed loans together with costs to the government waiting to absorb these losses.

The effects of the Basel Accords on the Asia Pacific region have been the subject of papers and books such as McAleer et al. (2013) and Matten and Trout (2005). Papers within the journals in this review include Anandarajan et al. (2007) on whether and the extent to which Australian banks use loan loss provisions (LLPs) for capital, earnings management, and signalling, and Wright et al. (2016) on the compliance by seven advanced countries with the Basel Committee's 2010 guidance on governance of banking organisations. There are a further two papers on internal credit risk modelling: Allen and Powell (2009) on internal credit risk modelling (for capital adequacy calculations) and sectoral exposure management, and da Veiga et al. (2012) on the performance of popular volatility models used to forecast credit value at risk $(\mathrm{VaR})$ thresholds under various distributional assumptions.

While Australia fared much better than many other economies during the Global Financial Crisis, McCarthy et al. (2015) conclude that it is important for the Australian banking regulator (APRA) to push for the requirements for banks to meet new standards, such as Basel III, ahead of time. As they note, notwithstanding the resilience of the sector, it is important for the regulators to remain proactive to ensure the safety of banks.

Hoang et al. (2014) highlight the evaluation of bank risk as an important issue to regulators. They then analyse whether market discipline impacts bank risk in the way that regulators would desire. The analysis suggests that market discipline helps reduce bank risk 
related to both equity and credit risk, and that this effect is stronger in the presence of a riskadjusted insurance premium and post the Global Financial Crisis. However, the presence of bank capital does not enhance the effect of market discipline. This latter finding, they conclude, "is a discouraging sign for bank regulators who endorse the symmetric and complementary role of the two Pillars (minimum capital adequacy as Pillar 1 and market discipline as Pillar 3) in protecting bank stability" (Hoang et al. 2014, 345).

The papers reviewed in this section have examined the effects of regulation or regulatory intervention, typically in the event of market failure and the general approach has been an investigation around a single event or the use of data from one country. The results of such papers will be more easily generalisable if carried out on an international sample from developed and emerging economies. Shen and Huang (2013) is one such international study on bank regulation where bank data from 85 countries was used to study the effects of earnings management on credit ratings and cost of debt. Future research can take a more preemptive rather than reactive approach to the investigation of regulatory effects. This can be facilitated via economic models that consider, among other functions, the assignment of authority and responsibility roles, and incentive alignment tasks (Armstrong et al. 2015).

\subsection{Bank supervision and governance}

Covering two pertinent questions about the structure of bank supervision, Barth et al. (2002) question whether there should be bank supervision by central banks and whether there should be multiple supervisors. Using data from 70 countries across developed, transitioning and emerging economies, they report an association between central bank supervision and non-performing loans while cases of multiple supervision are associated with lower capital ratios and higher liquidity risk. In a similar vein, Chen et al. (1996) consider whether differential monitoring costs result in foreign banks pricing loans to US firms differently compared to their US counterparts. This question was considered prior to the FDIC Improvement Act of 1991 in an environment of lax regulation of foreign banks in the US. The question of whether investors had sufficient information about bank stocks to allow a differentiation of risk levels when regulators controlled the information tightly is examined in Bremer and Pettway (2002). They investigate bank stock prices subject to Moody's downgrades between 1986 and 1998 and find sufficient information for investors to distinguish different risk levels among bank stock.

Risk management is an important aspect of bank governance. Gersbach and Wenzelburger (2010) question whether risk management sophistication promotes banking 
stability by comparing a simple banking system that makes use of an average rating and sophisticated systems where default risk is available for individual entrepreneurs. They find a trade-off between efficiency and stability due to efficient investment within a sophisticated system. The capital crunch hypothesis is studied by Horiuchi and Shimizu (1998) using the slowdown in the credit supply of Japanese banks in the early 1990s as the event. According to this hypothesis, banks will restrict credit supply in response to a decrease in capital. The results reject the capital crunch hypothesis in favour of the moral hazard hypothesis where an increase in equity capital in banks leads them to take a conservative approach towards credit supply expansion.

Risk management in the financial services sector will continue to warrant more research. Failures and weaknesses in corporate governance which did not prevent excessive risk taking in financial firms contributed to the Global Financial Crisis (Kirkpatrick 2009). Future work in this area should contemplate understanding these complex inter-relationships, including the risk appetite framework, to improve the process of managing risk in uncertain environments.

According to Armstrong et al. (2015), the fast-changing nature of banking, regulation and the public expectation of a safe financial environment introduce additional complexity when studying the governance and information environments of banks and financial institutions. However, it also provides opportunities for further research into bank structure and response to deregulation and new regulation within an evolving regulatory landscape (such as capital control), the substitutional roles of (external) regulation and internal governance mechanisms, and the roles and responsibilities of bank boards and regulators.

\section{Markets and Trading Regulation}

In an imperfect market where information asymmetry exists, financial market regulators and operators play an important role in regulating the behaviour of market participants. The consequences of good capital market governance may be difficult to isolate. It is for this reason that we observe many different performance measures in prior papers. Even though Daouk et al. (2006) note that, for policy setting purposes, it is important to examine how regulatory changes might affect multiple aspects of market performance, the focus in many papers is typically on the effect of a single regulatory change on one or two aspects of market performance. We identified three main areas trading regulation research in the Asia-Pacific region has focussed on: (1) trading by insiders and the effects of insider trading regulation; 
(2) the effects of banning short selling on market quality; and (3) the effects of changes to market mechanisms and takeover regulation.

\subsection{Restrictions on trading by insiders}

The trading by insiders with information superior to that possessed by the market has been the focus of several papers published internationally and in the regional journals that we examined. A seminal paper in the area by Bhattacharya and Daouk (2002) examines the enforcement of insider trading laws in 103 countries and how enforcement affects the cost of equity in a country.

Using data from New Zealand, Etebari et al. (2004) examine the effects of immediate versus delayed disclosures on the profitability of insiders' transactions and find significantly larger abnormal returns on transactions involving delayed disclosures. Similarly, Chang and Watson (2015) identify managerial incentives such as equity based compensation and director shareholdings affecting delayed trade disclosures by Australian directors. These delayed disclosed purchases and sales predict future returns. In another New Zealand study, Gilbert and Tourani-Rad (2008) examine the tightening of a previously ineffective regime with the introduction of the Securities Market Amendment Act 2002. Their findings show well-constructed insider trading laws significantly reduce the profitability of insider trades and prohibit insiders from trading on profitable information.

With data from 21 countries, Durnev and Nain (2007) show that private information trading is reduced when stricter insider trading regulations are in place. However, insider trading regulations are less effective for firms with higher agency costs. The authors argue that insiders can circumvent trading restrictions by covert expropriation of firm resources and reducing transparency. Their findings show that, in countries with strict insider regulations, firms with higher agency costs have more opaque earnings. Using a larger cross-country sample of 38 countries, Kusnadi (2015) examines the effect of insider trading restrictions on the volatility of earnings, a proxy for corporate risk-taking. He finds firms in countries with more restrictive insider trading regulations have higher country and industry-adjusted earnings volatility. Kusnadi (2015) concludes that managers engage in projects that are riskier when more effective corporate governance is in place, and potentially improves shareholder value.

Budsaratragoon et al. (2012) investigate whether the requirement to report insider trades is effective in an emerging market such as Thailand, an issue highlighted in prior work such as Bhattacharya and Daouk (2002) and Gilbert and Tourani-Rad (2008). That is, the 
enactment of regulation will have negligible effects on the trading by insiders if surveillance mechanisms are not in place or if regulation is not enforced. Consistent with their expectations, they find insiders contravene the requirements of regulation and trade prior to the release of earnings announcements. In addition, Thai corporate insiders earn significant abnormal returns when they trade, indicating that regulation is ineffective when enforcement is weak.

In papers published more recently, the focus has shifted from the impact of regulation to more detailed examination of trading by insiders. The work by Frino et al. (2013) differs from prior work discussed above in that it examines the behaviour of insiders by using data on illegal trades prosecuted by the SEC in the US. They find (1) a positive relationship between the volume traded by the insiders and the subsequent price change in the security; and (2) a negative relationship between the imposed sanction and volume traded by insiders. The findings suggest insiders consider the likelihood of being detected when deciding how best to exploit the illegal information.

Instead of focusing on trading on non-public knowledge of corporate news such as earnings and mergers, Griffin et al. (2014) examine trading by insiders around debt covenant violation disclosures. Public disclosure of the debt covenant violations and negotiation between managers and creditors are often made with substantial delay. Griffin et al. (2014) posit that the delay and likely negative investor response to the disclosure provide an opportunity for insiders to trade on the information. Using a sample of debt covenant violation disclosures in SEC filings, they find insiders time their trades in anticipation of the public disclosures.

Bartov and Faurel (2016) examine the stock price reaction to announcements of corporate insiders' early option exercises and sales of the acquired stock. They find a smaller negative stock price drift in the post-SOX period. They posit that the significant immediate stock price reaction in the post-SOX period results from the more timely dissemination of information due to the regulatory changes introduced by SOX. Chang et al. (2016a) use data from director trading and find results consistent with the claims of insider trading proponents by showing that director trading plays a crucial role in reducing information asymmetry and in improving information efficiency for stock market participants.

Incentives for trading and signalling from trading remain fertile avenues for future research. Further work needs to be done to exploit regional differences in insider trading regulation. Such papers can address differences in the definition of 'insider', and trading restrictions within securities markets and firm trading policies. Prospective studies can 
consider the personal incentives for trading such as compensation and shareholdings and individual characteristics such as age, education and risk outlook to humanise the trader to better understand their reasons for trading. Hillier et al. (2015) is an example of one such approach.

\subsection{Restrictions on short selling}

Worldwide stock market crashes beginning in October 1987 saw regulators seek ways to control abrupt stock price fluctuations and market volatility. One trading regulation that was studied intensely after the crash was the use of margin requirements (e.g., Lee and Yoo 1993). During the Global Financial Crisis in 2008 and the European debt crisis in 2010, attention was focussed on short selling regulations. While there is widespread evidence to suggest short sellers are essential to the efficient functioning of markets, regulators are pressured to apply restrictions on trading by these traders. The 2008 ban on short selling in Australia was the focus of the study by Do et al. (2012). Using the concept of the Law of One Price (LOP) as a proxy of market efficiency, they find the ban on short selling did not affect the working of the LOP. While violations of the LOP occurred frequently during the ban, they were quickly rectified. The findings provide an interesting contrast to papers such as Helmes et al. (2016) where the short-selling ban has been found to create frictions in the market, such as the deterioration in spreads, price impact and intraday volatility.

The removal of short-selling and margin trading bans in China on 31 March 2010 occurred at a time when many exchanges and regulators around the world were restricting short-selling activities. Using a matched-pair approach, Sharif et al. (2014) find the removal of the bans resulted in decreases in liquidity and volatility. Instead of concluding that the actions of short sellers have driven prices lower, the authors suggest it is the risk of trading with informed traders, i.e., the short sellers, which has driven prices lower.

Jung et al. (2013) investigate the effects of a unique regulatory change in Korea where individual investors are permitted to sell short some domestic stocks. The change in January 2008 reversed a 22-year ban on share-lending to individuals and did not affect institutional investors who continued to have access to facilities to borrow shares directly from each other. In contrast to the two papers previously discussed (Sharif et al. 2014; Do et al. 2012), the authors conclude that investors' short selling improved price discovery, evidenced by less serially correlated price changes and narrowed bid-ask spreads (Helmes et al. 2016).

The findings from Do et al. (2012) and Sharif et al. (2014) suggest regulators and academics may not fully understand what motivates short sellers or causes short selling. 
Papers such as Tan et al. (2015) examine short-selling activities in the context of arbitrages and McKenzie and Henry (2012) study the determinants of short selling during "normal" trading. Using a sample of 17 stocks traded on the Hong Kong stock market, McKenzie and Henry (2012) conclude that, company fundamentals and risk determine the level of short selling activities.

\subsection{Changes to market mechanisms and takeover regulation}

Several papers investigate the effects of changes to market mechanisms and takeover regulation. ${ }^{4}$ Bacha and Vila (1994) examine the introduction of a new futures contract on the volatility in the stock market and do not find any significant effect. Aitken et al. (2005) investigate the introduction of closing call auctions on the ASX and find no adverse effect on the cost of trading during continuous trading. Alampieski and Lepone (2009) find the reduction in the tick size in the Sydney Futures Exchange is associated with improved liquidity and reduced execution costs. He and Lepone (2014) examine the effects of trading on the ASX operated dark pool on market quality.

Chen et al. (2005) investigate the effects of price limit regulation on Chinese A- and B-shares. The authors find B-shares, due to their wider spreads, are more likely to hit price limits. Thus, they propose that exchanges should consider using midpoint prices to establish price limits and consider wider price limits for less liquid classes of stocks. Using data from the Taiwanese Stock Exchange, Chou et al. (2013) study the determinants of the limit-hit duration and find stocks with lower market capitalisation and higher idiosyncratic risk tend to have longer duration. ${ }^{5}$

Loughran et al. (1994) examine the reduction of regulatory interference in the setting of offering prices result in less short-run under-pricing in the 1990s. They find higher average initial returns in countries where the degree of government interference is greater. Chang et al. (2012) find IPO regulations implemented in Korea to promote fairness has the unintended consequences of distorting the pricing process and results in a high level of under-pricing in Korean IPOs.

The changes in takeover regulation in New Zealand from the 1990s to 2000s provide an ideal setting to examine the effects of regulatory changes. Firth (1997) notes that it is

\footnotetext{
${ }^{4}$ In 2011, Berkman and Comerton-Forde (2011) review the literature on market design and discuss examples of studies that have examined the impact of regulatory changes on price discovery in Australian and New Zealand stock markets.

${ }^{5}$ Chou et al. (2013) describes the limit-hit duration as "the length of time during which the trading price is locked at a limit price".
} 
interesting to study takeovers in New Zealand due to (1) the large number of takeovers relative to the size of the economy, (2) the unregulated nature of the market for corporate control, and (3) the proposed and implemented changes in regulations. Berkman and Navissi (2000) study the change in regulation requiring all listed New Zealand firms to adopt one of three proposed takeover provisions within a 16-month period ending on 31 December 1995. The three provisions range from liberal to restrictive, with the former resulting in making takeovers relatively easy while the latter providing a disincentive to potential bidders. They find firms that adopted liberal takeover policies experienced larger positive abnormal returns compared to those adopting more restrictive provisions. In a later study that examined an overlapping period to Berkman and Navissi (2000), Marshall and Anderson (2009) find that stronger regulations resulted in higher announcement returns and premiums for the target firms. The authors also report proportionally fewer bids following the tightening of takeover regulations. They suggest that management entrenchment may have increased with the changes.

In Australia, safeguards for target shareholders in takeover provisions are provided in Chapter 6 of the Corporations Act 2001. Under these requirements, the inability of bidders to acquire more than $20 \%$ of a firm in advance means that takeover bids have to be launched prior to the bidder holding a controlling stake, making them riskier than in other jurisdictions (Akhtar 2016). As Bugeja et al. (2016) describe however, members' schemes of arrangement are not captured within these principles. They take advantage of this difference to demonstrate a difference in the usage of takeover bids as opposed to schemes, showing that the likelihood of schemes is significantly higher when target firm concentration is higher, and that premiums are lower.

Bugeja (2011) looks at the regulation of foreign takeovers, finding that the type of firms subject to a foreign takeover are larger, have lower leverage, and operate in the resources sector. He also concludes that political concerns over the selling of Australian assets to foreigners are unjustified to the extent that target shareholders earn significantly higher abnormal returns from foreign bidders.

Investigations into regional differences in takeover regulation and their consequences on firm value and corporate control activity continue to make this an attractive area for future research. Future work should consider the impact of harmonisation of accounting standards and securities market regulation on cross border acquisitions. Some work on these ideas is beginning to emerge such as Francis et al. (2015) and Vidal-García and Vidal (2016). 
High frequency trading has changed how traders trade, the structure of markets, liquidity and price discovery. As a consequence there are regulatory and policy issues to be researched at the microstructure level (O'Hara 2015). Given regulation lags practice and high frequency trading is characterised by higher uncertainty, lower transparency and more complexity, future research can address the need for regulatory changes and their effect on fairness and equity to market participants.

\section{Corporate Governance Regulation}

The papers reviewed under the banner of corporate governance have generally focussed on the overall effects of corporate governance on aspects of the firm such as cost of capital or disclosure or alternatively, the effect of a specific governance mechanism.

Several papers investigate the effects of the introduction of ASX corporate governance guidelines in 2003. Beekes et al. (2015) is a follow-on from Beekes and Brown (2006), both examining the effects of corporate governance on firm disclosure informativeness. The 2015 study, based on an extended time series shows an increase in disclosure frequency and an improvement in the timeliness of bad versus good news reporting. Furthermore, firms have become more cautious with their disclosure practices although they continue to maintain balance in the reporting of good and bad news timeliness. Christensen et al. (2015) examine the effects of compliance with guidelines for small companies and find compliance is not associated with improved performance and earnings quality.

In a New Zealand setting, Chapple and Truong (2015) provide similar results to Beekes and Brown (2006) and Beekes et al. (2015) where disclosures improve subsequent to reforms; however, the relation to corporate governance is unclear. Firms with larger boards are found to improve, but the effect is diminished with audit committee independence and greater gender diversity, and no noted impact of board independence. Board independence, board financial expertise, and audit committee independence has also been shown to be associated with reduced earnings management behaviour in Australia (Hutchinson et al. 2008; Clout et al. 2013). On the other hand, Gray et al. (2016) show that in developed markets, such as Australia, there is no evidence that political and government connections are particularly valuable for shareholders, in contrast to studies examining the effect in developing economies (Chan et al. 2013).

Taking an alternate perspective, da Silva Rosa et al. (2008) examine the corporate governance of a set of firms that attracted the attention of ASIC. They find that, compared to 
a set of matched firms, the set of firms subject to ASIC actions are more likely to have weaker governance practices as prescribed by the ASX. Specifically, they are more likely to have the CEO as board chair, fewer non-executive members and a non-independent chair on the audit committee, and less likely to have a Big4 auditor. In a similar vein, Chapple et al. (2014) find that the frequency of ASX queries is positively associated with the occurrence of securities class actions, and firms subject to class actions exhibit weaker levels of corporate governance compared to a matched sample.

Best practice recommendations also have other positive outcomes, as shown in Baulkaran (2014) for a sample of firms listed on the Toronto Stock Exchange (TSX) over the 2003-2010 period. Higher firm value is associated with firms having individual director elections and providing detailed disclosure of voting results in these elections. Firms with an independent chairman, majority voting and detailed director election disclosure also have lower idiosyncratic risk. Investors learn about a firm's true governance policies where these policies are violated. Kouwenberg and Phunnarungsi (2013) examine the market reactions to news of violation of rules and regulations by Thai firms. While they find no difference in reaction between firms with high and low governance score, there is a large negative reaction when low governance firms are repeat offenders of these violations. In a similar manner, Akyol et al. (2012) examine the wealth effects of the Security and Exchange Commission's (SEC) proxy access rule to enable director nominations by shareholders. Focussing on how governance characteristics affect market reaction to the rule, they find more negative announcement effects for firms with high likelihoods of being targeted by shareholders. Announcement effects are positively related to the proportion of independent directors and the ratio of non-cash-based compensation, while being negatively correlated with size of the board.

Asymmetric payoffs to debt and equity holders lead to differential corporate governance impact on the cost of equity and the cost of debt. While Zhu (2014) shows in an international setting that good governance firms consistently have lower cost of equity and cost of debt, the effect on equity is more pronounced in countries with strong legal systems, detailed disclosure practices and good quality governments. On the other hand, in countries where legal protection is weak and transparency and government quality is poor, there is a stronger relation between corporate governance and cost of debt.

The effectiveness of individual governance mechanisms has been studied. For example, Merrett and Houghton (1999) use the records of board meetings to determine if directors are self-serving when takeover bids are received. They find this not to be the case, 
indicating that reputation is a strong governance mechanism. Han and Zhang (2016) compare the value effect to the agency cost effect on a firm from having a politically connected board. Using a regulatory change in China that forbids bureaucrats from sitting on boards of public firms, they report a dominance of the agency cost effect over a value effect. Baxter and Cotter (2009) and Bolton (2014) treat the audit committee as a governance mechanism and investigate its influence on earnings quality and firm performance respectively, with Bolton (2014) finding audit committee ownership to be a better explanator of firm performance than independence. The internal audit function is another effective governance mechanism where firms with the internal audit function are more likely to detect and self-report fraud. An internal governance system can be costly to implement and substitutes may be available in certain circumstances (Coram et al. 2008). Boo and Sharma (2008) study the complex interrelationship between internal governance, external audit monitoring and regulatory oversight and find that regulatory oversight substitutes for external monitoring. Other external governance mechanisms have been explored, such as media attention in Koning et al. (2010), who study the effect of media attention on Dutch firms reporting non-GAAP earnings.

While many studies have shown the beneficial effects of good corporate governance, some have questioned the role played by governance during the GFC. Adams (2012) posed the question of whether boards of financial firms were to blame for the financial crisis. She finds that the governance in financial firms was, on average, no worse than in non-financial firms. Based on governance score and indices, bank and non-bank financial firms appeared to be better governed than non-financial firms. Bank directors also earned less compensation and banks receiving bailouts had more independent boards than others not receiving bailouts. These findings call into question the governance measures that have been mentioned in recent governance policies because they appear to be insufficient to describe governance failures ascribed to financial firms. In another study, Adams and Ferreira (2012) investigate whether regulatory pressure on bank directors to attend meetings affected their behaviour. They found that while regulatory pressure was not sufficient alone to improve attendance records (bank directors fared worse than non-financial firm directors), their behaviour was influenced by explicit and implicit incentives.

Recent focus has been on the impact of diversity on the corporate governance function. In the future, we hope to understand better the complex effect of diversity on decision making and its overall impact on governance. Some work (e.g., Hutchinson et al. 2015) is already being done in this space. 


\subsection{Audit regulation}

Given the central importance of the audit function within the firm, much research has been dedicated to the investigation of its regulation. One of these earlier studies is Johnson et al. (1995) which reviews submissions made by audit firms to the Australian Companies and Securities Law Review Committee on limiting auditor liability. It find that larger audit firms with greater capacity to lobby and greater expected costs of litigation from unlimited liability overshadowed other respondents and tended to be more supportive of liability limitation than smaller audit firms.

Major developments in corporate governance regulations and recommendations for Australian audit committees, from 1976 to 2004 were studied by Munro and Buckby (2008) where three distinct regulatory periods were identified. They also conducted an empirical study on ASX300 firms with a 30 June 2004 year end, being the first year of the third period of regulation. The results show significant improvements in compliance with regulations and recommendations for audit committee formation, as reflected in the number of audit committee members, non-executive directors on the audit committee; financial expertise of audit committee members and the frequency of audit committee meetings.

The impact of the introduction of legally enforceable Australian Auditing Standards (ASAs) on the auditing profession was examined by Hecimovic et al. (2009) after its first year of implementation and later again by Hecimovic and Martinov-Bennie (2011) in a qualitative study. The later study focussed on the differences in impact of the ASAs on audit firms based on their size. Other regulatory aspects have also been examined, such as by Davis and Hay (2012) on the adequacy of audit self-regulation in New Zealand; Barros et al. (2014) on the productivity change among auditing companies in the UK as a result of the European Statutory Audit Directive; Griffin et al. (2009) on the impact of IFRS adoption on audit fees in New Zealand companies; Lee et al. (2013) on how the mandatory designation rule affected audit fees charged and audit hours rendered by auditors for firms free from the mandatory rule in Korea; and Chang et al. (2016b) on whether the audit partner disciplinary system in Taiwan helps to signal poor audit quality and enhance subsequent audit quality.

In an effort to regain public confidence in the auditing profession, Australia, like other jurisdictions has experienced substantial reforms to auditing regulation. To determine whether the objectives of these reforms have been achieved, Houghton et al. (2013) use qualitative interview data to study the perceptions of auditors, auditing standard setters and regulators in relation to the CLERP9 reforms. They develop a theoretical framework to evaluate whether these reforms are substantive enough to effect public confidence in reported 
financial data and competition in the audit market. Similarly, Chapple et al. (2005) examine changes to the regulation of corporate fundraising in Australia, as introduced by the Corporate Law Economic Reform Program Act 1999. They find the change to be associated with a decrease in forecast frequency and an increase in forecast value relevance, though not with forecast error. ${ }^{6}$

A change in the regulatory environment is sometimes met with resistance and reticence. For example, when $\mathrm{CEO}$ remuneration disclosure was initially required by the Company Law Review Act 1998, firms generally failed to comply until the requirements were formalised by Director and Executive Disclosures by Disclosing Entities (Clarkson et al. 2006). Investigating the effect of corporate governance on statutory executive stock option disclosure, Nelson et al. (2010) find an increase in overall compliance although there was reluctance to disclose on the more sensitive aspects of stock options.

\section{Disclosure Regulation}

Australia has long maintained rules that cover the provision of information to the stock market. The underlying purpose behind these rules, the Continuous Disclosure Regime (CDR), is to ensure the growth, efficiency and integrity of the Australian capital markets. The CDR obliges firms listed on the ASX to keep investors informed in a timely manner about price-relevant information. In September 1994, significant statutory civil and criminal sanctions were introduced to the (then) Corporations Law to enhance the enforcement of the existing ASX disclosure rules, specifically contained in section 1001A. Brown et al. (1999) describe this process as being consistent with Peltzman (1976)) description of the political process where regulation follows an alleged crisis. The New Zealand disclosure environment has closely followed that of Australia, also implementing continuous disclosure reforms.

Shortly after the introduction of the CDR, Brown et al. (1999) investigate the efficacy of the regime. At best, they find mixed results. Although total disclosures increased postsanctions, disclosures classified as price sensitive only became more frequent for firms without a large analyst following and for firms more likely to have revealed relatively bad news. Second, after controlling for intervening variables, the estimates suggest forecasts became less accurate and analyst disagreement remained at approximately pre-sanction levels. They also show share prices on the whole anticipated earlier the value-relevant components of a firm's preliminary final statement; however, the information advantage is

\footnotetext{
${ }^{6}$ Carey et al. (2014) provide an in depth review of the research on auditor independence post-CLERP9.
} 
concentrated among firms of less interest to institutional investors. Finally, they find despite the increase in the frequency with which firms have filed price sensitive documents postsanction, the weight placed on each document's ability to explain return volatility is not statistically different from the pre-sanction period. More recently, Russell (2015) shows that under the CDR, firms with high information asymmetry disclose more information, however, disclosure in the presence of high information asymmetry further increases the asymmetry in the market.

Over the life of the CDR, there have been different approaches regarding enforcement actions. Hsu et al. (2012) identify three distinct periods where enforcement action has increased. Overall, they find that analyst forecast accuracy and dispersion improved in response to the introduction of CDR. However, increased enforcement from 1998 resulted in a deterioration in forecast dispersion for small firms, possibly due to a decrease in private information flows to analysts as regulators became more proactive in enforcing the ban on selective disclosures. In a similar vein, Chang et al. (2014) reach comparable conclusions with investor relations disclosures, being unrelated to forecast dispersions due to low analyst following. ${ }^{7}$

Litigation risk has often been proposed as an explanation for why firms disclose information, and in particular with regard to bad news. Unlike in the U.S. where much of this research has been undertaken, Australia and New Zealand are characterised as having relatively low litigation risk. Hsu (2009) documents that despite the low risk of litigation, Australian firms are more likely to make continuous disclosures in the presence of bad news relative to good news. She attributes this result to market forces and regulatory scrutiny as being sufficient to impose a bad news bias in disclosure. Similarly, in New Zealand, Dunstan et al. (2011) find that subsequent to the introduction of continuous disclosure rules, firms in general are more likely to issue management earnings forecasts to pre-empt earnings announcements, implying that regulatory reforms may have greater benefits in low litigation environments. Jackson et al. (2015) extend these studies to examine whether increases in litigation risk affect the strategic timing of management earnings forecasts. Consistent with the theme in Dunstan et al. (2011), they found that while the propensity to delay forecasts decreases with increases in litigation risk, this is a general effect and is not proportionately

\footnotetext{
${ }^{7}$ Australia is noted for relatively low analyst following compared to the U.S. Jackson et al. (2015) note that only $38 \%$ of their sample have analyst coverage, while Carvajal et al. (2015) report that $31 \%$ of Australian listed firms in 2012 are covered by analysts according to I/B/E/S.
} 
greater for bad news. Characteristics of the board of directors however, appears to be unrelated to the compliance of CDR (Matolcsy et al. 2012).

Another important aspect of the CDR is the ASX's ability to query firms regarding significant changes in price or trading volume unaccompanied by any disclosure. Drienko and Sault (2011) explain the process by which queries are made: first the ASX submits a query to which a firm is required to respond. At the time of the response, both the initial query and the reply are announced to the market, while a failure to respond would result in a trading halt. The findings demonstrate positive wealth and volume effects with query announcements, and unexplained abnormal returns in the pre-announcement period fail to reverse in the event a firm announces the absence of information to explain the pre-query activity. The absence of reversal is consistent with the New Zealand evidence of Marsden et al. (2008), but inconsistent with Australian results in Gong (2007).

Surrounding the implementation of IFRS in Australia, Wee et al. (2014) examine the disclosure requirements under the CDR. They record communication about changes in financial reports even when the changes relate to accounting rather than economic events, and more disclosure by firms experiencing an adverse change in earnings, as would be required under the disclosure rules. When economic performance is stronger, however, firms provide less discussion of the accounting effects of IFRS adoption.

Outside of Australia and New Zealand, studies have examined the disclosure regulations in other countries. Griffin et al. (2011) examine the costs imposed by Regulation Fair Disclosure (Reg FD) in the U.S. While there are many similarities between CDR and Reg FD, the main difference relates to when information needs to be disclosed. While CDR requires all price sensitive information to be disclosed immediately to the market, Reg FD does not have the same requirements. The requirement in Reg FD is to prohibit selective disclosure, meaning that firms have the discretion to choose whether to disclose or not, once the decision to disclose has been made it must be made to the entire market. Griffin et al. (2011) find that Reg FD levies three types of enforcement and disclosure costs for investors when firms breach the regulation by selectively disclosing information.

On the Tokyo Stock Exchange, Kubota and Takehara (2016) report that while the newly introduced quarterly disclosure requirement did not always reduce information asymmetry and increase liquidity within firms, it allowed good and bad firms to choose their signalling equilibrium. Ota (2010) examines the requirement by the stock exchange in Japan for firms to provide management earnings forecasts and finds the forecasts provide useful information for the analysts and the market. 
Dedman et al. (2009) find the combination of official regulation and voluntary selfregulation mean market forces are generally sufficient to ensure adequate disclosure. In the Netherlands where regulators have taken a light handed approach (opposed to the heavy approach in the U.S.), Koning et al. (2010) find that after a peak in negative media attention for non-GAAP earnings reporting, firms altered their behaviour by making small adjustments to GAAP earnings. Using data from Singapore, Cheng et al. (2011) conclude that voluntary disclosure in annual reports can be regarded as an important determinant of preannouncement information precision in markets with low regulation and analyst following.

While we focus on continuous disclosure, as reflected in the literature, other disclosure regulations have been examined. These include Frost (2007) on environmental reporting practices in Australia, Frost et al. (2004) on ethical investment, and Clarkson et al. (2011) and Loh et al. (2015) on the corporate, social and environmental disclosure practices of firms in Australia. With the growing focus around climate issues we expect an increase in papers on environmental and corporate social responsibility disclosures to grow. While disclosures on these areas are still voluntary, any discussions on potential regulations will open up potentially fruitful venues for future research.

\section{Accounting Standard Setting}

The final main area of regulation research we have identified relates to the accounting standard setting process. Accounting standards exist because they are a relatively efficient solution to the agency problem that arises when there is a separation of ownership and control of a firm (Brown and Tarca 2001). Gipper et al. (2013) provides further discussion of the political nature of the standard setting process using the US Financial Accounting Standard Board as a setting.

The literature on accounting standard setting can be generally classified into two streams: (1) papers using theories of regulation to document the evolution of accounting standards, and (2) papers examining the real effects and consequences of adopting new accounting standards.

Australian and New Zealand researchers have a formidable international reputation for standard setting. This reputation extends to the vast literature on IFRS adoption, including its effect on issues as varied as analyst earnings forecasts (e.g., Chalmers et al. 2012; Cotter et al. 2012), language translation of international standards (Evans et al. 2015), disclosure (e.g., Crawford et al. 2014), policy choice (e.g., Stent et al. 2015), educational perspectives (Jackling et al. 2012), preparers perspectives (Jones and Higgins 2006), and legal aspects 
(Bradbury and Van Zij1 2006). Given the breadth and depth of research on IFRS adoption in the region, we intentionally leave aside the move towards adoption of IFRS as it is too vast to do justice to within the scope of this review. While there have been reflections on IFRS adoption a decade after the fact (e.g., Brown and Tarca 2012; McGregor 2012), it may be worthwhile for a targeted review of the literature to consolidate our knowledge of the empirical evidence on the benefits and costs of adoption.

\subsection{Evolution of Accounting Standards}

A number of theories of regulation have been used to explore the development of accounting standard setting in Australia and New Zealand. Using a public choice model, whereby the regulatory process is characterised by the observation of a perceived crisis, regulations are developed as an equilibrium result between the demand and supply of selfinterested parties, Rahman et al. (1994) describe the development of a standard on investment property investing in New Zealand.

Klumpes (1994) use an agenda entrance model to describe the development of pension accounting standards in Australia. The agenda entrance model has four stages: (1) issues creation, largely due to a crisis; (2) issue expansion where proponents mobilise support; (3) agenda entrance where the issue is formally addressed by the regulator; and (4) a decision stage where interested parties try to influence the regulator's decision. As Walker and Robinson (1994) note, this assumes the existence of a single regulatory body.

A competing regulatory agencies approach is used by Walker and Robinson (1994) to explain the related party transactions and cash flow reporting issues in Australia. This approach addresses the shortfall in models of regulation that ignore potential conflicts of interest and domain maintenance activities that occur when there are multiply standardsetting agencies. Gordon and Morris (1996) then use a cycle model of regulation to explore equity accounting, which comprises of four elements: (1) variations in practice; (2) crisis bring attention to the accounting issue at hand; (3) forces opposing standardisation, mainly managers wishing to retain flexibility in accounting choice; and (4) forces favouring standardisation.

As Gordon and Morris (1996) acknowledge, these four theories of regulation share much overlap among them, but emphasise different aspects of policy-making. In short, while each model adequately explains the situations studied, they are largely chosen as they better explain the history of the issues examined. 
Ryan et al. (2007) take a different tack in examining the politics of financial reporting in the public sector. They utilise the theoretical framework of Puxty et al. (1987) which "describes accounting regulation in advanced capitalist societies as the outcome of recurring struggles within, and between, the organizational principles of market forces, state bureaucratic controls and community ideals, and the parties, agents and interest groups that represent them" (Ryan et al. 2007, 475). In January 2000, the merging of the Public Sector Accounting Standards Board with the Australian Accounting Standards Board (AASB) resulted in a sector neutral approach to standard setting, which as Ryan et al. (2007) argue resulted in the new AASB to be captured by a mix of private interests, government strategy and international developments. They conclude that consistent with Puxty et al. (1987) model, a corporatist approach exists in Australia, where private interests have dominated the actions of standard setters over those of the public sector.

\subsection{Consequences of Accounting Standards}

Studies focussing on the consequences of the introduction of regulated accounting standards concentrate largely on the complex issue of intangibles. Anderson and Zimmer (1992) examine the reactions to the regulation for goodwill with the introduction of AAS18 in 1985. The introduction of AAS18 required firms to amortise purchased goodwill. However, a number of firms either did not comply or took evasive actions to mitigate the effects of this standard. Empirically, they observed that the unintended consequence of the regulation designed to achieve uniformity in practice actually resulted in a lower reflection of economic reality when it came to the recognition of goodwill.

A similar finding is documented by Ritter and Wells (2006) in regards to AASB138 on identifiable intangible assets. While disclosures on these types of intangibles are found to be value relevant, the application of the restrictive recognition rules in AASB138, it is likely these disclosures will be greatly diminished. These results suggest that while regulation may be viewed as a low cost and efficient method of alleviating the agency problem (Brown and Tarca 2001), in this setting where accounting practices pre-regulation have been relatively efficient and constraints on the recognition of these assets have been sufficient, additional regulations are predicted to have a negative effect on the usefulness of the information provided.

In contrast, however, Chalmers et al. (2011) find that a goodwill impairment regime has had the opposite effect. The regulation from IFRS appears to not have had the same unintended consequences documented by Anderson and Zimmer (1992), in that the purpose 
of better reflecting the economic reality of goodwill has been met, and Australian firms appear to be complying with the standards. Guthrie and Pang (2013) also find that compliance with the goodwill allocation requirements general improved over the period from 2005 to 2010.

Godfrey and Warren (1995) similarly examine the economic consequence of AAS17 which required firms to bring leases onto the balance sheet. They found that the introduction of AAS17 resulted in firms reducing their reliance on finance leases, and increasing their reliance on non-lease debt and equity financing. They also found that the greater a firm's reliance on finance leases prior to AAS17, the greater the subsequent capital structure adjustments. Contrary to Anderson and Zimmer (1992), Godfrey and Warren (1995) do not document any large degree of non-compliance with the new regulation.

Changes in accounting standards, however, do not necessarily have an effect on users. Using a sample of German early IFRS adopters, Lopes et al. (2013) show that whether noncontrolling interests are reported as equity or non-equity are priced in the same manner. They conclude that equity markets are efficient in their processing of information regardless of the influence of standard setters in mandating classifications.

While we acknowledge the exclusion of studies on IFRS, there is still a dearth of studies examining the regulatory impact of standard setting. A significant explanation for this is that researchers and standard setters have different incentives which has resulted in a gulf between the type of research standard setters demand, and the supply of research by academics (Schipper 1994). However, Brown and Howieson (1998) conclude, there is much optimism to be had in this line of research. More recently this has been observed with the creation of the AASB Academic Panel which is expected to expand the interactions between academic researchers and standard setters, ${ }^{8}$ and the 'Accounting \& Finance/IASB Forum on Consequences of IFRS for Capital Markets, Managers, Auditors and Standard-setters' held in Hong Kong in 2015 which bought researchers and standard setters together.

One specific area for which more work is needed is in regards to the strong move towards fair value accounting encapsulated within IFRS. Both Stevenson (2012) and AmelZadeh and Meeks (2013) point out that there have been allegations that fair value accounting was a contributing cause of the GFC. In a case study, Goncharov and Van Triest (2014) highlight the unintended consequences of fair value accounting in increasing agency costs for minority shareholders.

\footnotetext{
8 http://www.aasb.gov.au/News/Australian-Accounting-Standards-Board-Academic-Panel-launched-toimprove-standard-setting
} 


\section{Summary}

In this paper, we review the research on regulation in the Asia-Pacific region. We do this by analysing six leading regional accounting and finance journals - Abacus, Accounting \& Finance, Australian Accounting Review, Australian Journal of Management, International Review of Finance and the Pacific-Basin Finance Journal. We identify five main themes of regulation research relating to: (1) banking and financial institutions; (2) markets and trading; (3) corporate governance; (4) disclosure; and (5) accounting standard setting. In the identification of the main themes we acknowledge it is not an exhaustive list of topics, and within the themes we do not identify every paper. Rather, we synthesise the literature on what we identify as the most prevalent areas and provide some suggestions for future directions.

Our review on regulation research has led to two significant areas where future research can be conducted. The first is the move to a high frequency world where markets have significantly altered because of technology and high frequency trading (HFT). Regulation however, has not kept up with practice. This situation creates opportunities for researchers to proactively examine the implications of new regulation or regulatory changes. There is potential for the effects and implications of regulation on insider trading, short selling and disclosure in the new high frequency world to be re-examined. This is in light of changes to how traders trade, how markets behave, and how liquidity and price discovery occur.

The second area is on the regulation of corporate social responsibility (CSR) reporting. Globally, firms are increasingly producing CSR reports, an umbrella term for nonfinancial reports, which provides information to allow assessment of environmental, social and governance performance. Cohen and Simnett (2014) provide an agenda of future research opportunities on assurance services for CSR reporting including investigating the quality of CSR assurance services and the importance of integrated reporting and related assurance issues.

We do note a lack of research debate surrounding regulatory issues, in that little is being done to explicitly confirm prior research, or provide conflicting viewpoints. Most papers tend to approach their research questions in isolation from prior literature. Our hope, in this review, is to help potential and current researchers address this perceived immaturity and grow the regulatory research conversation in the region. 


\section{References}

Adams, R. B., 2012, Governance and the financial crisis, International Review of Finance 12, 7-38.

Adams, R. B., and D. Ferreira, 2012, Regulatory pressure and bank directors' incentives to attend board meetings, International Review of Finance 12, 227-248.

Agusman, A., G. S. Cullen, D. Gasbarro, G. S. Monroe, and J. K. Zumwalt, 2014, Government intervention, bank ownership and risk-taking during the indonesian financial crisis, Pacific-Basin Finance Journal 30, 114-131.

Aitken, M., C. Comerton-Forde, and A. Frino, 2005, Closing call auctions and liquidity, Accounting \& Finance 45, 501-518.

Akhtar, F., 2016, The probability of a firm making a takeover bid: An empirical analysis of Australian firms, Australian Journal of Management 41, 27-54.

Akyol, A. C., W. F. Lim, and P. Verwijmeren, 2012, Governance characteristics and the market reaction to the SEC's proxy access rule, International Review of Finance 12, 175-195.

Alampieski, K., and A. Lepone, 2009, Impact of a tick size reduction on liquidity: Evidence from the Sydney Futures Exchange, Accounting \& Finance 49, 1-20.

Allen, D. E., and R. Powell, 2009, Transitional credit modelling and its relationship to market value at risk: An Australian sectoral perspective, Accounting \& Finance 49, 425-444.

Allen, F., and E. Carletti, 2010, An overview of the crisis: Causes, consequences, and solutions, International Review of Finance 10, 1-26.

Amel-Zadeh, A., and G. Meeks, 2013, Bank failure, mark-to-market and the financial crisis, Abacus 49, 308-339.

Anandarajan, A., I. Hasan, and C. McCarthy, 2007, Use of loan loss provisions for capital, earnings management and signalling by Australian banks, Accounting \& Finance 47, 357-379.

Anderson, D., and I. Zimmer, 1992, Reactions to regulation of accounting for goodwill, Accounting \& Finance 32, 27-50.

Angkinand, A. P., W. Sawangngoenyuang, and C. Wihlborg, 2010, Financial liberalization and banking crises: A cross-country analysis, International Review of Finance 10, 263-292.

Armstrong, C., W. R. Guay, H. Mehran, and J. Weber, 2015, The role of information and financial reporting in corporate governance: a review of the evidence and the implications for banking firms and the financial services industry, Economic Policy Review forthcoming. 
Avkiran, N. K., Y. Zhu, D. W. L. Tripe, and K. Walsh, 2015, Can foreign banks compete in China?, Accounting \& Finance forthcoming.

Bacha, O., and A. F. Vila, 1994, Futures markets, regulation and volatility: The case of the Nikkei stock index futures markets, Pacific-Basin Finance Journal 2, 201-225.

Barros, C. P., E. Couto, and A. Samagaio, 2014, Productivity analysis of UK auditing firms, Australian Accounting Review 24, 381-393.

Barth, J. R., L. G. Dopico, D. E. Nolle, and J. A. Wilcox, 2002, Bank safety and soundness and the structure of bank supervision: A cross-country analysis, International Review of Finance 3, 163-188.

Bartov, E., and L. Faurel, 2016, Sarbanes-Oxley Act and patterns in stock returns around executive stock option exercise disclosures, Accounting \& Finance 56, 297-332.

Bátiz-Lazo, B., and M. Billings, 2012, Accounting regulation and management discretion-a case note, Abacus 48, 414-437.

Baulkaran, V., 2014, A quiet revolution in corporate governance: An examination of voluntary best practice governance policies, International Review of Finance 14, 459483.

Baxter, P., and J. Cotter, 2009, Audit committees and earnings quality, Accounting \& Finance 49, 267-290.

Beekes, W., and P. Brown, 2006, Do better-governed Australian firms make more informative disclosures?, Journal of Business, FInance \& Accounting 33, 422-450.

Beekes, W., P. Brown, and Q. Zhang, 2015, Corporate governance and the informativeness of disclosures in australia: A re-examination, Accounting \& Finance 55, 931-963.

Benson, K., P. M. Clarkson, T. Smith, and I. Tutticci, 2015a, A review of accounting research in the Asia Pacific region, Australian Journal of Management 40, 36-88.

Benson, K., R. Faff, and T. Smith, 2015b, Injecting liquidity into liquidity research, PacificBasin Finance Journal 35, 533-540.

Benson, K., R. W. Faff, and T. Smith, 2014, Fifty years of finance research in the Asia Pacific Basin, Accounting \& Finance 54, 335-363.

Berkman, H., and C. Comerton-Forde, 2011, Market microstructure: A review from down under, Accounting \& Finance 51, 50-78.

Berkman, H., and F. Navissi, 2000, Rules governing the transfer of ownership: Wealth effects and the influence of ownership structure, International Review of Finance 1, 229-244.

Bhattacharya, U., and H. Daouk, 2002, The world price of insider trading, The Journal of Finance 57, 75-108. 
Bolton, B., 2014, Audit committee performance: Ownership vs. Independence - did SOX get it wrong?, Accounting \& Finance 54, 83-112.

Boo, E. f., and D. Sharma, 2008, Effect of regulatory oversight on the association between internal governance characteristics and audit fees, Accounting \& Finance 48, 51-71.

Bradbury, M., and T. Van Zijl, 2006, Due process and the adoption of IFRS in New Zealand, Australian Accounting Review 16, 86-94.

Bremer, M., and R. H. Pettway, 2002, Information and the market's perceptions of Japanese bank risk: Regulation, environment, and disclosure, Pacific-Basin Finance Journal 10, 119-139.

Brown, P., and B. Howieson, 1998, Capital markets research and accounting standard setting, Accounting \& Finance 38, 5-28.

Brown, P., and A. Tarca, 2001, Politics, processes and the future of australian accounting standards, Abacus 37, 267-296.

Brown, P., and A. Tarca, 2007, Achieving high quality, comparable financial reporting: A review of independent enforcement bodies in australia and the United Kingdom, Abacus 43, 438-473.

Brown, P., and A. Tarca, 2012, Ten years of IFRS: Reflections and expectations, Australian Accounting Review 22, 224.

Brown, P., S. L. Taylor, and T. S. Walter, 1999, The impact of statutory sanctions on the level and information content of voluntary corporate disclosure, Abacus 35, 138-162.

Budsaratragoon, P., D. Hillier, and S. Lhaopadchan, 2012, Applying developed-country regulation in emerging markets: An analysis of Thai insider trading, Accounting \& Finance 52, 1013-1039.

Bugeja, M., 2011, Foreign takeovers of Australian listed entities, Australian Journal of Management 36, 89-107.

Bugeja, M., R. da Silva Rosa, H. Izan, and S. Ngan, 2016, To scheme or bid? Choice of takeover method and impact on premium, Australian Journal of Management 41, 212-243.

Carey, P. J., G. S. Monroe, and G. Shailer, 2014, Review of post-CLERP 9 Australian auditor independence research, Australian Accounting Review 24, 370-380.

Carmichael, J., 2001, Financial regulation in the 21st century, Pacific-Basin Finance Journal 9, 313-321.

Carvajal, M., J. J. Coulton, and A. B. Jackson, 2015, Earnings benchmark hierarchy, Accounting \& Finance forthcoming. 
Chalmers, K., G. Clinch, J. M. Godfrey, and Z. Wei, 2012, Intangible assets, IFRS and analysts' earnings forecasts, Accounting \& Finance 52, 691-721.

Chalmers, K. G., J. M. Godfrey, and J. C. Webster, 2011, Does a goodwill impairment regime better reflect the underlying economic attributes of goodwill?, Accounting \& Finance 51, 634-660.

Chan, K. H., P. L. L. Mo, and A. Y. Zhou, 2013, Government ownership, corporate governance and tax aggressiveness: Evidence from China, Accounting \& Finance 53, 1029-1051.

Chang, K., Y.-C. Kim, Y. S. Kim, and J. H. Thornton Jr, 2012, Unintended regulatory consequences: Evidence from the Korean IPOs, Pacific-Basin Finance Journal 20, 292-309.

Chang, M., L. Hooi, and M. Wee, 2014, How does investor relations disclosure affect analysts' forecasts?, Accounting \& Finance 54, 365-391.

Chang, M., X. Qian, J. Yu, and Y. See, 2016a, Does director trading change the information environment?, Australian Journal of Management forthcoming.

Chang, M., and I. Watson, 2015, Delayed disclosure of insider trades: Incentives for and indicators of future performance?, Pacific-Basin Finance Journal 35, Part A, 182197.

Chang, W.-C., Y.-S. Chen, L.-T. L. Chou, and C.-H. Ko, 2016b, Audit partner disciplinary actions and financial restatements, Abacus 52, 286-318.

Chapple, L., P. M. Clarkson, and C. J. Peters, 2005, Impact of the Corporate Law Economic Reform Program Act 1999 on initial public offering prospectus earnings forecasts, Accounting \& Finance 45, 67-94.

Chapple, L., V. J. Clout, and D. Tan, 2014, Corporate governance and securities class actions, Australian Journal of Management 39, 525-547.

Chapple, L., and T. P. Truong, 2015, Continuous disclosure compliance: Does corporate governance matter?, Accounting \& Finance 55, 965-988.

Chen, A. H., S. C. Mazumdar, and M.-w. Hung, 1996, Regulations, lender identity and bank loan pricing, Pacific-Basin Finance Journal 4, 1-14.

Chen, G.-M., K. A. Kim, and O. M. Rui, 2005, A note on price limit performance: The case of illiquid stocks, Pacific-Basin Finance Journal 13, 81-92.

Cheng, E. C. M., S. M. Courtenay, and A. R. Rahman, 2011, Effects of prior voluntary disclosure on earnings announcements in an environment with low information and regulation, Pacific-Basin Finance Journal 19, 308-329. 
Chong, B.-S., M.-H. Liu, and Y. Altunbas, 1996, The impact of universal banking on the risks and returns of Japanese financial institutions, Pacific-Basin Finance Journal 4, 181-195.

Chou, P.-H., R. K. Chou, K.-C. Ko, and C.-Y. Chao, 2013, What affects the cool-off duration under price limits?, Pacific-Basin Finance Journal 24, 256-278.

Christensen, J., P. Kent, J. Routledge, and J. Stewart, 2015, Do corporate governance recommendations improve the performance and accountability of small listed companies?, Accounting \& Finance 55, 133-164.

Clarkson, P., A. L. Van Bueren, and J. Walker, 2006, Chief executive officer remuneration disclosure quality: Corporate responses to an evolving disclosure environment, Accounting \& Finance 46, 771-796.

Clarkson, P. M., M. B. Overell, and L. Chapple, 2011, Environmental reporting and its relation to corporate environmental performance, Abacus 47, 27-60.

Clout, V. J., L. Chapple, and N. Gandhi, 2013, The impact of auditor independence regulations on established and emerging firms, Accounting Research Journal 26, 88108.

Cohen, J. R., and R. Simnett, 2014, CSR and assurance services: A research agenda, Auditing: A Journal of Practice \& Theory 34, 59-74.

Coram, P., C. Ferguson, and R. Moroney, 2008, Internal audit, alternative internal audit structures and the level of misappropriation of assets fraud, Accounting \& Finance 48, 543-559.

Cotter, J., A. Tarca, and M. Wee, 2012, IFRS adoption and analysts' earnings forecasts: Australian evidence, Accounting \& Finance 52, 395-419.

Crawford, L., D. Lont, and T. Scott, 2014, The effect of more rules-based guidance on expense disclosure under international financial reporting standards, Accounting \& Finance 54, 1093-1124.

da Silva Rosa, R., J. Filippetto, and A. Tarca, 2008, Asic actions: Canaries for poor corporate governance?, Accounting Research Journal 21, 67-86.

da Veiga, B., F. Chan, and M. McAleer, 2012, It pays to violate: How effective are the Basel Accord penalties in encouraging risk management?, Accounting \& Finance 52, 95116.

Daouk, H., C. M. C. Lee, and D. Ng, 2006, Capital market governance: How do security laws affect market performance?, Journal of Corporate Finance 12, 560-593.

Davis, K., 1994, Prudential regulation and Australian credit unions, Australian Journal of Management 19, 31-46. 
Davis, M., and D. Hay, 2012, An analysis of submissions on proposed regulations for audit and assurance in New Zealand, Australian Accounting Review 22, 303-316.

Dedman, E., S. Mouselli, Y. U. N. Shen, and A. W. Stark, 2009, Accounting, intangible assets, stock market activity, and measurement and disclosure policy-views from the U.K, Abacus 45, 312-341.

Do, B., V. Do, and D. Chai, 2012, Does the 2008 short sale ban affect the enforcement of the law of one price? Evidence from Australia, Accounting \& Finance 52, 117-144.

Drienko, J., and S. J. Sault, 2011, The impact of company responses to exchange queries on the Australian equity market, Accounting \& Finance 51, 923-945.

Dunstan, K., G. Gallery, and T. P. Truong, 2011, Public regulatory reform and management earnings forecasts in a low private litigation environment, Accounting \& Finance 51, 437-465.

Durnev, A. A., and A. S. Nain, 2007, Does insider trading regulation deter private information trading? International evidence, Pacific-Basin Finance Journal 15, 409433.

Etebari, A., A. Tourani-Rad, and A. Gilbert, 2004, Disclosure regulation and the profitability of insider trading: Evidence from New Zealand, Pacific-Basin Finance Journal 12, 479-502.

Evans, L., R. Baskerville, and K. Nara, 2015, Colliding worlds: Issues relating to language translation in accounting and some lessons from other disciplines, Abacus 51, 1-36.

Firth, M., 1997, Takeovers in New Zealand: Motives, stockholder returns, and executive share ownership, Pacific-Basin Finance Journal 5, 419-440.

Francis, J. R., S. X. Huang, and I. K. Khurana, 2015, The role of similar accounting standards in cross-border mergers and acquisitions, Contemporary Accounting Research.

Francis, W. B., and M. Osborne, 2010, On the behavior and determinants of risk-based capital ratios: Revisiting the evidence from UK banking institutions, International Review of Finance 10, 485-518.

Frino, A., S. Satchell, B. Wong, and H. Zheng, 2013, How much does an illegal insider trade?, International Review of Finance 13, 241-263.

Frost, G., G. Michelson, S. Van Der Laan, and N. Wailes, 2004, Bringing ethical investment to account, Australian Accounting Review 14, 3-9.

Frost, G. R., 2007, The introduction of mandatory environmental reporting guidelines: Australian evidence, Abacus 43, 190-216.

Fu, Y., S.-C. Lee, L. Xu, and R. Zurbruegg, 2015, The effectiveness of capital regulation on bank behavior in China, International Review of Finance 15, 321-345. 
Gersbach, H., and J. A. N. Wenzelburger, 2010, Sophistication in risk management, bank equity, and stability, International Review of Finance 10, 63-91.

Gilbert, A., and A. Tourani-Rad, 2008, The impact of regulations on the informational basis of insider trading, Australian Journal of Management 33, 407-435.

Gipper, B., B. J. Lombardi, and D. J. Skinner, 2013, The politics of accounting standardsetting: A review of empirical research, Australian Journal of Management 38, 523551.

Godfrey, J. M., and S. M. Warren, 1995, Lessee reactions to regulation of accounting for leases, Abacus 31, 201-228.

Goncharov, I., and S. Van Triest, 2014, Unintended consequences of changing accounting standards: The case of fair value accounting and mandatory dividends, Abacus 50, 341-367.

Gong, N., 2007, Effectiveness and market reaction to the stock exchange's inquiry in Australia, Journal of Business, FInance \& Accounting 34, 1141-1168.

Gordon, I., and R. D. Morris, 1996, The equity accounting saga in Australia: Cyclical standard setting, Abacus 32, 153-177.

Gray, S., I. Harymawan, and J. Nowland, 2016, Political and government connections on corporate boards in Australia: Good for business?, Australian Journal of Management 41, 3-26.

Griffin, P. A., D. H. Lont, and K. McClune, 2014, Insightful insiders? Insider trading and stock return around debt covenant violation disclosures, Abacus 50, 117-145.

Griffin, P. A., D. H. Lont, and B. Segal, 2011, Enforcement and disclosure under regulation fair disclosure: An empirical analysis, Accounting \& Finance 51, 947-983.

Griffin, P. A., D. H. Lont, and Y. Sun, 2009, Governance regulatory changes, International Financial Reporting Standards Adoption, and New Zealand audit and non-audit fees: Empirical evidence, Accounting \& Finance 49, 697-724.

Guthrie, J., and T. T. Pang, 2013, Disclosure of goodwill impairment under AASB 136 from 2005-2010, Australian Accounting Review 23, 216-231.

Han, J., and G. Zhang, 2016, Politically connected boards, value or cost: Evidence from a natural experiment in China, Accounting \& Finance forthcoming.

He, W. P., and A. Lepone, 2014, Determinants of liquidity and execution probability in exchange operated dark pool: Evidence from the Australian Securities Exchange, Pacific-Basin Finance Journal 30, 1-16.

Hecimovic, A., and N. Martinov-Bennie, 2011, The differential impact of the force of law Australian auditing standards, Australian Accounting Review 21, 183-192. 
Hecimovic, A., N. Martinov-Bennie, and P. Roebuck, 2009, The force of law: Australian auditing standards and their impact on the auditing profession, Australian Accounting Review 19, 1-10.

Helmes, U., J. Henker, and T. Henker, 2016, Effect of the ban on short selling on market prices and volatility, Accounting \& Finance forthcoming.

Hillier, D., A. Korczak, and P. Korczak, 2015, The impact of personal attributes on corporate insider trading, Journal of Corporate Finance 30, 150-167.

Hoang, K. T., R. Faff, and M. Haq, 2014, Market discipline and bank risk taking, Australian Journal of Management 39, 327-350.

Hogan, W., 1997, What directions from Wallis?, Australian Accounting Review 7, 40-44.

Horiuchi, A., and K. Shimizu, 1998, The deterioration of bank balance sheets in Japan: Risktaking and recapitalization, Pacific-Basin Finance Journal 6, 1-26.

Hossain, M., P. K. Jain, and S. Mitra, 2013, State ownership and bank equity in the AsiaPacific region, Pacific-Basin Finance Journal 21, 914-931.

Houghton, K. A., M. Kend, and C. Jubb, 2013, The CLERP 9 audit reforms: Benefits and costs through the eyes of regulators, standard setters and audit service suppliers, Abacus 49, 139-160.

Howieson, B. A., 2009, Agenda formation and accounting standards setting: Lessons from the standards setters, Accounting \& Finance 49, 577-598.

Hsu, G. C.-M., 2009, Impact of earnings performance on price-sensitive disclosures under the Australian continuous disclosure regime, Accounting \& Finance 49, 317-339.

Hsu, G. C. M., S. Lindsay, and I. Tutticci, 2012, Inter-temporal changes in analysts' forecast properties under the Australian continuous disclosure regime, Accounting \& Finance $52,1101-1123$.

Hubbard, R., and D. E. Vetter, 1996, An empirical comparison of published replication research in accounting, economics, finance, management, and marketing, Journal of Business Research 35, 153-164.

Hutchinson, M., J. Mack, and K. Plastow, 2015, Who selects the 'right' directors? An examination of the association between board selection, gender diversity and outcomes, Accounting \& Finance 55, 1071-1103.

Hutchinson, M. R., M. Percy, and L. Erkurtoglu, 2008, An investigation of the association between corporate governance, earnings management and the effect of governance reforms, Accounting Research Journal 21, 239-262.

Jackling, B., B. Howieson, and R. Natoli, 2012, Some implications of IFRS adoption for accounting education, Australian Accounting Review 22, 331-340. 
Jackson, A. B., G. Gallery, and M. C. A. Balatbat, 2015, The impact of litigation risk on the strategic timing of management earnings forecasts, Accounting \& Finance 55, 467495.

Johnson, R. B., D. J. Stokes, and D. G. Watts, 1995, Auditor preferences for liability limitation, Accounting \& Finance 35, 135-153.

Jones, S., and A. D. Higgins, 2006, Australia's switch to International Financial Reporting Standards: A perspective from account preparers, Accounting \& Finance 46, 629-652.

Jung, C. S., W. Kim, and D. W. Lee, 2013, Short selling by individual investors: Destabilizing or price discovering?, Pacific-Basin Finance Journal 21, 1232-1248.

Kane, E. J., 2000, The dialectical role of information and disinformation in regulationinduced banking crises, Pacific-Basin Finance Journal 8, 285-308.

Kirkpatrick, G., 2009, The corporate governance lessons from the financial crisis, OECD Journal: Financial Market Trends 2009, 61-87.

Klumpes, P. J. M., 1994, The politics of rule development: A case study of Australian pension fund accounting rule-making, Abacus 30, 140-159.

Koning, M., G. Mertens, and P. Roosenboom, 2010, The impact of media attention on the use of alternative earnings measures, Abacus 46, 258-288.

Kouwenberg, R., and V. Phunnarungsi, 2013, Corporate governance, violations and market reactions, Pacific-Basin Finance Journal 21, 881-898.

Kubota, K., and H. Takehara, 2016, Information asymmetry and quarterly disclosure decisions by firms: Evidence from the Tokyo Stock Exchange, International Review of Finance 16, 127-159.

Kusnadi, Y., 2015, Insider trading restrictions and corporate risk-taking, Pacific-Basin Finance Journal 35, 125-142.

Lee, D. H., S. M. Kim, K. W. Oh, and S. W. Yoo, 2013, New auditors' decisions for released firms from the mandatory auditor designation rule: Evidence from South Korea, Australian Accounting Review 23, 341-356.

Lee, S. B., and T. Y. Yoo, 1993, Margin regulation and stock market volatility: Further evidence from Japan, Korea and Taiwan, Pacific-Basin Finance Journal 1, 155-174.

Linnenluecke, M. K., X. Chen, X. Ling, T. Smith, and Y. Zhu, 2016, Emerging trends in Asia-Pacific finance research: A review of recent influential publications and a research agenda, Pacific-Basin Finance Journal 36.

Loh, C. M., C. Deegan, and R. Inglis, 2015, The changing trends of corporate social and environmental disclosure within the Australian gambling industry, Accounting \& Finance 55, 783-823. 
Lopes, A. I., I. Lourenço, and M. Soliman, 2013, Do alternative methods of reporting noncontrolling interests really matter?, Australian Journal of Management 38, 7-30.

Loughran, T., J. R. Ritter, and K. Rydqvist, 1994, Initial public offerings: International insights, Pacific-Basin Finance Journal 2, 165-199.

Marsden, A., R. Poskitt, and C. Wang, 2008, An empirical analysis of the NZX's price query system, Pacific Accounting Review 20, 4-28.

Marshall, B. R., and H. D. Anderson, 2009, Regulation and target takeover returns: Is there a link?, Pacific-Basin Finance Journal 17, 395-412.

Matolcsy, Z., J. Tyler, and P. Wells, 2012, Is continuous disclosure associated with board independence?, Australian Journal of Management 37, 99-124.

Matten, C., and P. Trout, 2005, The Basel Accord, Application and Implementation in AsiaPasific, City and Financial Publishing, Edited by Tatersall J. and Smith R.

McAleer, M., J. Á. Jiménez-Martín, and T. Pérez-Amaral, 2013, International evidence on GFC - Robust forecasts for risk management under the Basel Accord, Journal of Forecasting 32, 267-288.

McCarthy, S., B. Oliver, and M.-L. Verreynne, 2015, Bank financing and credit rationing of Australian SMEs, Australian Journal of Management forthcoming.

McGregor, W., 2012, Personal reflections on ten years of the IASB, Australian Accounting Review 22, 225-238.

McKenzie, M., and Ó. T. Henry, 2012, The determinants of short selling: Evidence from the Hong Kong equity market, Accounting \& Finance 52, 183-216.

Merrett, D., and K. Houghton, 1999, Takeovers and corporate governance: Whose interests do directors serve?, Abacus 35, 223-240.

Miller, M. C., 1995, The credibility of Australian financial reporting: Are the co-regulation arrangements working?, Australian Accounting Review 5, 3-16.

Moonesinghe, R., M. J. Khoury, and A. C. J. Janssens, 2007, Most published research findings are false - but a little replication goes a long way, PLoS Med 4, e28.

Munro, L., and S. Buckby, 2008, Audit committee regulation in Australia: How far have we come?, Australian Accounting Review 18, 310-323.

Nelson, J., G. Gallery, and M. Percy, 2010, Role of corporate governance in mitigating the selective disclosure of executive stock option information, Accounting \& Finance 50, 685-717.

O'Hara, M., 2015, High frequency market microstructure, Journal of Financial Economics $116,257-270$. 
Ota, K., 2010, The value relevance of management forecasts and their impact on analysts' forecasts: Empirical evidence from Japan, Abacus 46, 28-59.

Peltzman, S., 1976, Toward a more general theory of regulation, The Journal of Law \& Economics 19, 211-240.

Previts, G. J., H. M. Roybark, and E. N. Coffman, 2003, Keeping watch! Recounting twentyfive years of the office of chief accountant, U.S. Securities and Exchange Commission, 1976-2001, Abacus 39, 147-185.

Puxty, A. G., H. C. Willmott, D. J. Cooper, and T. Lowe, 1987, Modes of regulation in advanced capitalism: Locating accountancy in four countries, Accounting, Organizations and Society 12, 273-291.

Rahman, A. R., L. W. Ng, and G. D. Tower, 1994, Public choice and accounting standard setting in New Zealand: An exploratory study, Abacus 30, 98-117.

Ritter, A., and P. Wells, 2006, Identifiable intangible asset disclosures, stock prices and future earnings, Accounting \& Finance 46, 843-863.

Russell, M., 2015, Continuous disclosure and information asymmetry, Accounting Research Journal 28, 195-224.

Ryan, C., J. Guthrie, and R. O. N. Day, 2007, Politics of financial reporting and the consequences for the public sector, Abacus 43, 474-487.

Schipper, K., 1994, Academic accounting research and the standard setting process, Accounting Horizons 8, 61-73.

Sharif, S., H. D. Anderson, and B. R. Marshall, 2014, Against the tide: The commencement of short selling and margin trading in mainland China, Accounting \& Finance 54, 1319-1355.

Shen, C.-H., and Y.-L. Huang, 2013, Effects of earnings management on bank cost of debt, Accounting \& Finance 53, 265-300.

Stent, W., M. E. Bradbury, and J. Hooks, 2015, Insights into accounting choice from the adoption timing of International Financial Reporting Standards, Accounting \& Finance forthcoming.

Stevenson, K. M., 2012, Financial reporting: Hearing the GFC message? What message?, Accounting \& Finance 52, 9-20.

Tan, K. J. K., J. M. Lee, and R. W. Faff, 2015, Short-selling pressure and last-resort debt finance: Evidence from 144A high-yield risk-adjusted debt, Accounting \& Finance, forthcoming.

Taylor, S., 2009, Capital markets regulation: How can accounting research contribute?, Australian Accounting Review 19, 319-325. 
Vidal-García, J., and M. Vidal, 2016, IFRS harmonization and foreign direct investment, Analyzing the Relationship between Corporate Social Responsibility and Foreign Direct Investment (IGI Global, 31-48.

Walker, R. G., and S. P. Robinson, 1994, Competing regulatory agencies with conflicting agendas: Setting standards for cash flow reporting in Australia, Abacus 30, 119-139.

Wee, M., A. Tarca, and M. Chang, 2014, Disclosure incentives, mandatory standards and firm communication in the IFRS adoption setting, Australian Journal of Management 39, 265-291.

Wright, S., E. Sheedy, and S. Magee, 2016, International compliance with new Basel Accord principles for risk governance, Accounting \& Finance forthcoming.

Yan, X., M. Skully, K. Avram, and T. Vu, 2014, Market discipline and deposit guarantee: Evidence from Australian banks, International Review of Finance 14, 431-457.

Zhu, F., 2014, Corporate governance and the cost of capital: An international study, International Review of Finance 14, 393-429. 


\section{Table 1 Aims and Scope of Journals}

The table reproduce the Aims and Scope provided on each journal's website. The six journals are Abacus, Accounting and Finance (AccFin), Australian Accounting Review (AAR), Australian Journal of Management (AJM), International Review of Finance (IRF) and Pacific-Basin Finance Journal (PBFJ).

\begin{tabular}{ll}
\hline Journal & Aims and Scope \\
\hline Abacus & "Since 1965 Abacus has consistently provided a vehicle for the expression of independent and \\
& critical thought on matters of current academic and professional interest in accounting, finance and \\
& business. The journal reports current research; critically evaluates current developments in theory \\
& and practice; analyses the effects of the regulatory framework of accounting, finance and business; \\
& and explores alternatives to, and explanations of, past and current practices."
\end{tabular}

(Source: http://onlinelibrary.wiley.com/journal/10.1111/(ISSN)1467-6281/homepage/ProductInformation.html)

AccFin "Accounting \& Finance enjoys an excellent reputation as an academic journal that publishes articles addressing significant research questions from a broad range of perspectives. The journal:

- publishes significant contributions to the accounting, finance, business information systems and related disciplines

- develops, tests, or advances accounting, finance and information systems theory, research and practice

- publishes theoretical, empirical and experimental papers that significantly contribute to the disciplines of accounting and finance

- publishes articles using a wide range of research methods including statistical analysis, analytical work, case studies, qualitative research, field research and historical analysis

- applies economic, organizational and other theories to accounting and finance phenomena and publishes occasional special issues on themes such as on research methods in management accounting."

(Source: http://onlinelibrary.wiley.com/journal/10.1111/(ISSN)1467-629X/homepage/ProductInformation.html)

AAR "AAR is positioned at the intersection of business and academe and features articles by leading practitioners and researchers. It aims to provide in-depth discussion and critical analysis of developments affecting professionals in all areas of finance, accounting and business.

Articles published in Australian Accounting Review should be relevant to the journal's primary readership: the Australasian and international academic, professional, business, government and regulatory communities. Review articles on issues relevant to AAR's primary readership are also favourably received. Motivation for articles should be located in current events/problems that affect the business and professional communities, and in the literature. Articles must display a high level of critical analysis, employ an appropriate research approach, provide empirical evidence to support conclusions, and establish the local and international significance of their findings. Replications of international studies that simply apply an accepted methodology to a data set in a different context are not acceptable unless the broad implications of conclusions are articulated, and are of relevance to a wider set of circumstances. Data that purport to be contemporary need to be so. Papers must be scholarly and have the authority of academic rigour yet be accessible to non-academic readers."

(Source: http://onlinelibrary.wiley.com/journal/10.1111/(ISSN)1835-2561/homepage/ProductInformation.html)

AJM "The objectives of the Australian Journal of Management are to encourage and publish research in the field of management. The terms management and research are both broadly defined. The former includes the management of firms, groups, industries, regulatory bodies, government, and other institutions. The latter encompasses both discipline and problem-based research. Consistent with the policy, the Australian Journal of Management publishes peer-reviewed research in accounting, applied economics, finance, industrial relations, political science, psychology, statistics, and other disciplines. This is providing that the application is to management and research in areas such as marketing, corporate strategy, operations management, organisation development, decision analysis, and other problem-focused paradigms." 


\begin{tabular}{ll}
\hline Journal & \multicolumn{1}{c}{ Aims and Scope } \\
\hline IRF & "The International Review of Finance (IRF) publishes high-quality research on all aspects of \\
& financial economics, including traditional areas such as asset pricing, corporate finance, market \\
& microstructure, financial intermediation and regulation, financial econometrics, financial \\
engineering and risk management, as well as new areas such as markets and institutions of \\
emerging market economies, especially those in the Asia-Pacific region. In addition, the Letters \\
Section in IRF is a premium outlet of letter-length research in all fields of finance. The length of \\
the articles in the Letters Section is limited to a maximum of eight journal pages." \\
(Source: http://onlinelibrary.wiley.com/journal/10.1111/(ISSN)1468-2443/homepage/ProductInformation.html)
\end{tabular}

PBFJ "The Pacific-Basin Finance Journal is aimed at providing a specialized forum for the publication of academic research on capital markets of the Asia-Pacific countries. Primary emphasis will be placed on the highest quality empirical and theoretical research in the following areas:

- Market Micro-structure;

- Investment and Portfolio Management;

- Theories of Market Equilibrium;

- Valuation of Financial and Real Assets;

- Behavior of Asset Prices in Financial Sectors;

- Normative Theory of Financial Management;

- Capital Markets of Development;

- Market Mechanisms"

(Source: http://www.journals.elsevier.com/pacific-basin-finance-journal) 
Table 2 Data Descriptive Statistics

The table provides the count of the articles reviewed and included in the discussion.

\begin{tabular}{|c|c|c|c|c|c|}
\hline \multirow[b]{2}{*}{ Journal } & \multirow[b]{2}{*}{ Years Included } & \multicolumn{4}{|c|}{ Number of Articles } \\
\hline & & All & $\begin{array}{c}\text { 'Regulation' in } \\
\text { Text }\end{array}$ & $\begin{array}{l}\text { 'Regulation' } \\
\text { in Abstract/ } \\
\text { Keywords }\end{array}$ & $\begin{array}{l}\text { Selected to } \\
\text { include }\end{array}$ \\
\hline
\end{tabular}

Panel A: Number of articles reviewed and selected

Abacus

$1990-2016$

$1990-2016$

Accounting \& Finance

Australian Accounting Review ${ }^{9}$

Australian Journal of Management

International Review of Finance ${ }^{9}$

Pacific-Basin Finance Journal ${ }^{9}$

$1991-2016$

$1990-2016$

$2000-2016$

$1993-2016$

$\begin{array}{rr}526 & 287 \\ 808 & 305 \\ 630 & 357 \\ 469 & 120 \\ 218 & 76 \\ 798 & 348 \\ 3,449 & 1,493\end{array}$

\begin{tabular}{cc}
41 & 23 \\
42 & 52 \\
34 & 16 \\
13 & 15 \\
9 & 15 \\
67 & 26 \\
206 & 147 \\
& \\
Accounting & \\
Standard & \\
Setting & Other Sections \\
\hline
\end{tabular}

Panel B: Number of articles included in each review area

\begin{tabular}{|c|c|c|c|c|c|}
\hline $\begin{array}{l}\text { Banking and } \\
\text { Financial } \\
\text { Institutions }\end{array}$ & $\begin{array}{c}\text { Markets and } \\
\text { Trading }\end{array}$ & Corporate Governance & Disclosure & $\begin{array}{l}\text { Accounting } \\
\text { Standard } \\
\text { Setting }\end{array}$ & Other Sections \\
\hline
\end{tabular}

\begin{tabular}{|c|c|c|c|c|c|c|}
\hline Abacus & 1 & 1 & 4 & 6 & 10 & 1 \\
\hline Accounting \& Finance & 6 & 10 & 15 & 10 & 10 & 1 \\
\hline Australian Accounting Review ${ }^{10}$ & 1 & & 7 & 1 & 5 & 2 \\
\hline Australian Journal of Management & 3 & 5 & 2 & 2 & 2 & 1 \\
\hline International Review of Finance ${ }^{11}$ & 7 & 2 & 5 & 1 & & \\
\hline Pacific-Basin Finance Journal $^{11}$ & 8 & 14 & 1 & 1 & & 2 \\
\hline
\end{tabular}

\footnotetext{
${ }^{9}$ The Australian Accounting Review Pacific-Basin Finance Journal and International Review of Finance were established in 1991, 1993 and 2000, respectively.

${ }^{10}$ According to the journal, the readership for the Australian Accounting Review comprises Accounting practitioners and academics. This is reflected in the concentration of articles in the sections on Corporate Governance and Accounting Standard Setting.

${ }^{11}$ According to their Aims and Scope (see Table 1), these two journals do not seek to publish research in the area of Accounting.
} 